\title{
Aniba rosaeodora (Var. amazonica Ducke) Essential Oil: Chemical Composition, Antibacterial, Antioxidant and Antitrypanosomal Activity
}

\author{
Amanda Mara Teles ${ }^{1}{ }^{D}$, João Victor Silva-Silva ${ }^{2}$, Juan Matheus Pereira Fernandes ${ }^{2}$, Kátia da Silva Calabrese ${ }^{2, * \mathbb{D}}$, \\ Ana Lucia Abreu-Silva ${ }^{3}{ }^{(D}$, Silvio Carvalho Marinho ${ }^{4}$, , Adenilde Nascimento Mouchrek ${ }^{5}$, Victor Elias \\ Mouchrek Filho ${ }^{5}$ and Fernando Almeida-Souza $2,3, * \mathbb{D}$ \\ 1 Pós-Graduação em Saúde do Adulto, Universidade Federal do Maranhão, 65080-805 São Luís, Brazil; \\ damarateles@hotmail.com \\ 2 Laboratório de Imunomodulação e Protozoologia, Instituto Oswaldo Cruz, Fiocruz, \\ 21040-900 Rio de Janeiro, Brazil; jvss2906@gmail.com (J.V.S.-S.); juan.fernandes222@gmail.com (J.M.P.F.) \\ 3 Pós-graduação em Ciência Animal, Universidade Estadual do Maranhão, 65055-310 São Luís, Brazil; \\ abreusilva.ana@gmail.com \\ 4 Laboratório de Óleos Essenciais, Universidade Federal do Maranhão, 65065-545 São Luís, Brazil; \\ silviomarinho@yahoo.com.br \\ 5 Laboratório de Controle de Qualidade de Alimentos e Água, Universidade Federal do Maranhão, \\ 65065-545 São Luís, Brazil; adenild@bol.com.br (A.N.M.); victor.mouchrek@ufma.br (V.E.M.F.) \\ * Correspondence: calabrese@ioc.fiocruz.br (K.d.S.C.); fernandoalsouza@gmail.com (F.A.-S.)
}

Citation: Teles, A.M.; Silva-Silva, J.V.; Fernandes, J.M.P.; Calabrese, K.d.S.; Abreu-Silva, A.L.; Marinho, S.C.; Mouchrek, A.N.; Filho, V.E.M.; Almeida-Souza, F. Aniba rosaeodora (Var. amazonica Ducke) Essential Oil: Chemical Composition, Antibacterial Antioxidant and Antitrypanosomal Activity. Antibiotics 2021, 10, 24 https://doi.org/10.3390/ antibiotics 10010024

Received: 27 November 2020 Accepted: 28 December 2020 Published: 30 December 2020

Publisher's Note: MDPI stays neutral with regard to jurisdictional clai$\mathrm{ms}$ in published maps and institutional affiliations.

Copyright: () 2020 by the authors. Licensee MDPI, Basel, Switzerland. This article is an open access article distributed under the terms and conditions of the Creative Commons Attribution (CC BY) license (https:// creativecommons.org/licenses/by/ $4.0 /)$.
Abstract: Aniba rosaeodora is one of the most widely used plants in the perfumery industry, being used as medicinal plant in the Brazilian Amazon. This work aimed to evaluate the chemical composition of $A$. rosaeodora essential oil and its biological activities. A. rosaeodora essential oil presented linalool $(93.60 \%)$ as its major compound. The $A$. rosaeodora essential oil and linalool showed activity against all the bacteria strains tested, standard strains and marine environment bacteria, with the lower minimum inhibitory concentration being observed for $S$. aureus. An efficient antioxidant activity of $A$. rosaeodora essential oil and linalool ( $\mathrm{EC}_{50}: 15.46$ and $6.78 \mu \mathrm{g} / \mathrm{mL}$, respectively) was evidenced by the inhibition of the 2,2-azinobis- (3-ethylbenzothiazoline-6-sulfonic acid) (ABTS) radical. The antitrypanosomal activity of $A$. rosaeodora essential oil and linalool was observed at high concentrations against epimatigote forms (inhibitory concentration for 50\% of parasites (IC 50 ): $150.5 \pm 1.08$ and $198.6 \pm 1.12 \mu \mathrm{g} / \mathrm{mL}$, respectively), and even higher against intracellular amastigotes of T. cruzi $\left(\mathrm{IC}_{50}: 911.6 \pm 1.15\right.$ and $249.6 \pm 1.18 \mu \mathrm{g} / \mathrm{mL}$, respectively). Both A. rosaeodora essential oil and linalool did not exhibit a cytotoxic effect in BALB/c peritoneal macrophages, and both reduced nitrite levels in unstimulated cells revealing a potential effect in NO production. These data revealed the pharmacological potential of $A$. rosaeodora essential oil and linalool, encouraging further studies.

Keywords: rosewood; linalool; marine bacteria; ABTS; Trypanosoma cruzi; cytotoxicity; nitrite; nitric oxide

\section{Introduction}

In recent decades, many studies have concentrated on the search for potential antimicrobials, with an increase in the worldwide spending on finding new antimicrobial agents. Faced with bacterial resistance to antibiotic treatment as well as the discovery of new pathogens, the need for new antimicrobials arises [1].

There are promising reports of different plant-derived natural phytochemicals, and a growing interest in exploring their potential [2]. Medicinal plants have been used around the world for various purposes, just as their active chemical compounds have been used to combat various diseases. Essential oils are well known for their pharmacological activities, including antibacterial [3] and trypanocidal activity [4], and may represent a promising source of new natural drugs. 
Aniba rosaeodora Ducke, Lauraceae is a large tree that reaches $30 \mathrm{~m}$ in height, with yellow-brown bark (hence the name rosewood) and grows in the Amazon region (Figure 1A) [5]. Rosewood essential oil (Figure 1B) is widely used in the perfumery industry and its extraction for industrial purposes began in the interior of the state of Pará, Brazil, around 1930 [6]. All parts of the tree are fragrant, although only the trunk wood is harvested and hydrodistilled to obtain rosewood oil, a valuable product. The species has been used in the Amazon as a medicinal plant to control epileptic seizures, to compose regional fragrances and as an ornamental plant [7].

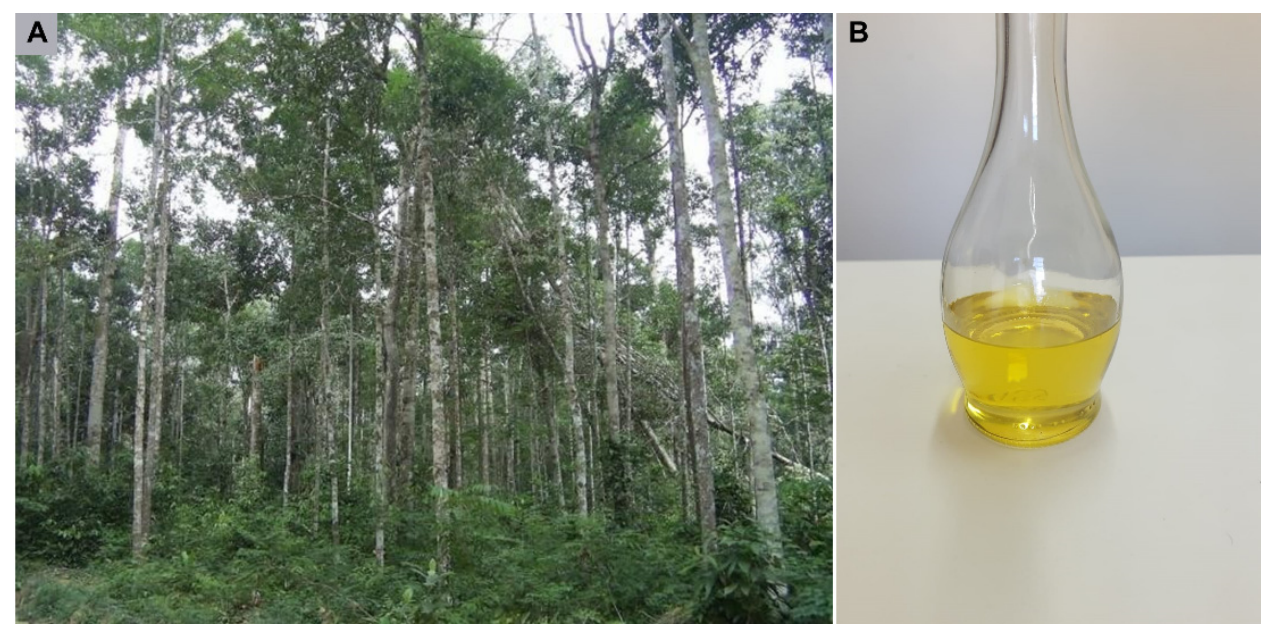

Figure 1. Aniba rosaeodora tree (A) and essential oil (B).

Rosewood oil is a colorless to pale yellow liquid with a woody floral fragrance, containing monoterpenic alcohol linalool as the main constituent. It is of interest to the flavor and fragrance industries because it is transformed into several valuable derivatives [8]. There are few reports of pharmacological properties of Rosewood oil associated with its chemical profile. These properties are the result of the synergism of all the molecules present in the oil or reflect the activity of its major compound linalool, presenting antibacterial and antifungal [9,10], antioxidant [11] and antiprotozoan properties [12].

Available data on the biological activity of rosewood essential oil are quite limited, because most studies have focused on linalool, its main constituent [13]. Thus, this work aims to evaluate the chemical composition of Aniba rosaeodora essential oil extracted in the Amazon biome, as well as its antibacterial, antioxidant and trypanocidal activity.

\section{Results}

\subsection{Physical and Chemical Characterization of A. rosaeodora Essential Oil}

The yield of $A$. rosaeodora essential oil obtained from dried leaves thin branches was $2.8 \%$. The oil showed a yellow color and a clean appearance (Figure 1B), and presented a density of $0.89 \mathrm{~g} / \mathrm{mL}$ at $25^{\circ} \mathrm{C}$, and a refractive index (ND 25) of 1.459. It was soluble in ethanol $70 \%$ in a ratio of 1:2. Chemical compounds identified and quantified in $A$. rosaeodora essential oil are presented in the chromatogram (Figure 2) and Table 1. Three compounds were identified and enumerated accordingly with elution order and retention time. The major constituent of $A$. rosaeodora essential oil was linalool with $93.60 \%$. In addition, $\alpha-$ terpinolene and linalool cis-oxide were identified and quantified at 3.37\% and 3.03\%, respectively. 


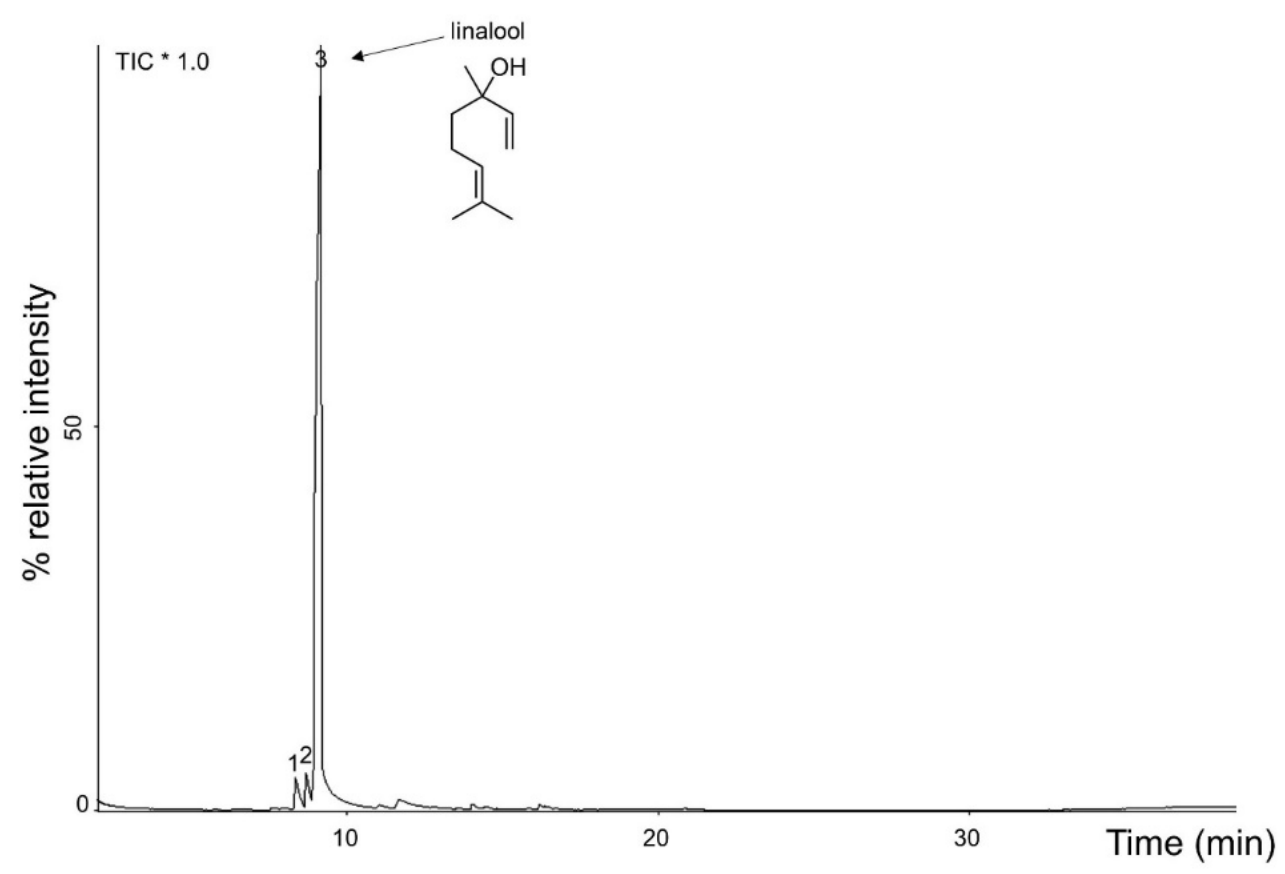

Figure 2. Chromatogram of Aniba rosaeodora essential oil. * TIC: total ion chromatogram.

Table 1. Chemical composition of Aniba rosaeodora essential oil.

\begin{tabular}{cccc}
\hline Peak & Compounds & Retention Time (min) & Peak Area (\%) ${ }^{\mathbf{1}}$ \\
\hline 1 & a-terpinolene & 8.361 & 3.37 \\
2 & linalool cis-oxide & 8.702 & 3.03 \\
3 & linalool & 9.177 & 93.60 \\
\hline
\end{tabular}

\footnotetext{
${ }^{1}$ Peak area percentage in relation to peak total area.
}

\subsection{Antimicrobial Activity of A. rosaeodora Essential Oil and Linalool}

Bacteria from the marine environment were evaluated by the disc-diffusion method against $A$. rosaeodora, linalool and several reference antibiotics (Table 2). The bacteria culture displayed inhibition halos ranging from 7 to $25 \mathrm{~mm}$, besides the non-inhibition presented in some cultures. Comparing linalool with $A$. rosaeodora essential oil, we found that $A$. rosaeodora was more efficient against Aeromonas caviae and Enterococcus faecalis than the standard linalool. Linalool exhibited greater activity against Klebsiella pneumonia and Providencia stuartii than $A$. rosaeodora essential oil, while both compounds presented the same activity against Aeromonas hydrophila. The susceptibility test performed with antibiotics showed that $E$. faecalis was the strain that presented sensibility for all the antibiotics analyzed, while the other four strains displayed mixed sensibility to the antibiotics.

The preliminary antibacterial activity against standard strain bacteria evaluated by the disc-diffusion method showed a growth inhibitory halo on $A$. rosaeodora essential oil and linalool disks against Gram-positive (Staphylococcus aureus) and Gram-negative strains (Escherichia coli, Pseudomonas aeruginosa and Salmonella sp.) (Table 3). Gram-positive bacteria exhibited the highest inhibition halo from both essential oil and linalool. The minimum inhibitory concentration (MIC) of $A$. rosaeodora essential oil ranged from 250 to $450 \mu \mathrm{g} / \mathrm{mL}$ against the tested strains. As observed in the disc-diffusion method, $S$. aureus was the strain more sensible to $A$. rosaeodora essential oil and linalool activity by MIC analysis. Likewise, both methodologies showed that $A$. rosaeodora essential oil presented better antimicrobial activity than linalool to all strains analyzed. 
Table 2. Inhibitory zone diameters of Aniba rosaeodora essential oil, linalool and antibiotics on different bacteria isolated from marine environment after $24 \mathrm{~h}$ of treatment.

\begin{tabular}{cccccc}
\hline & \multicolumn{4}{c}{ Bacteria Strain } \\
\cline { 2 - 6 } Compounds/Antibiotics & $\begin{array}{c}\text { Aeromonas } \\
\text { caviae }\end{array}$ & $\begin{array}{c}\text { Aeromonas } \\
\text { hydrophila }\end{array}$ & $\begin{array}{c}\text { Enterococcus } \\
\text { faecalis }\end{array}$ & $\begin{array}{c}\text { Klebsiella } \\
\text { pneumoniae }\end{array}$ & $\begin{array}{c}\text { Providencia } \\
\text { stuartii }\end{array}$ \\
\hline A. rosaeodora essential oil & $22.33 \pm 0.577$ & $11.33 \pm 0.577$ & $21.33 \pm 0.577$ & $10.33 \pm 0.577$ & $9.33 \pm 0.577$ \\
linalool & $7.33 \pm 0.577$ & $11.66 \pm 0.577$ & $13.33 \pm 0.577$ & $11.66 \pm 0.577$ & $11.33 \pm 0.577$ \\
pipemidic acid & $22.33 \pm 0.577$ & $21.66 \pm 0.577$ & $18.66 \pm 0.577$ & $22.33 \pm 0.577$ & $22.33 \pm 0.577$ \\
ampicillin & $0 \pm 0.00$ & $0 \pm 0.00$ & $15.66 \pm 0.577$ & $0 \pm 0.00$ & $0 \pm 0.00$ \\
cefotaxime & $24.67 \pm 0.577$ & $23.66 \pm 0.577$ & $17.66 \pm 0.577$ & $17.33 \pm 0.577$ & $25.33 \pm 0.577$ \\
cefoxitin & $0 \pm 0.00$ & $13.66 \pm 0.577$ & $22.66 \pm 0.577$ & $8.33 \pm 0.577$ & $15.33 \pm 0.577$ \\
chloramphenicol & $23.33 \pm 1.155$ & $20.66 \pm 0.577$ & $24.66 \pm 0.577$ & $13.66 \pm 0.577$ & $13.33 \pm 0.577$ \\
erythromycin & $0 \pm 0.00$ & $0 \pm 0.00$ & $25.66 \pm 1.527$ & $0 \pm 0.00$ & $0 \pm 0.00$ \\
gentamycin & $17.66 \pm 0.577$ & $14.66 \pm 0.577$ & $22.33 \pm 0.577$ & $14.33 \pm 0.577$ & $14.33 \pm 0.577$ \\
lincomycin & $0 \pm 0.00$ & $0 \pm 0.00$ & $29.66 \pm 0.577$ & $0 \pm 0.00$ & $0 \pm 0.00$ \\
oxacillin & $0 \pm 0.00$ & $0 \pm 0.00$ & $18.66 \pm 0.577$ & $0 \pm 0.00$ & $0 \pm 0.00$ \\
sulfazotrin & $21.66 \pm 0.577$ & $19.66 \pm 0.577$ & $21 \pm 1.00$ & $20.33 \pm 0.577$ & $21.33 \pm 0.577$ \\
tetracycline & $10.33 \pm 0.577$ & $22.66 \pm 0.577$ & $19.66 \pm 0.577$ & $0 \pm 0.00$ & $18.33 \pm 0.577$ \\
vancomycin & $0 \pm 0.00$ & $0 \pm 0.00$ & $20.66 \pm 0.577$ & $0 \pm 0.00$ & $0 \pm 0.00$ \\
\hline
\end{tabular}

Data represents mean \pm standard deviation of experiment realized in triplicate.

Table 3. Inhibitory zone diameters and minimum inhibitory concentration of Aniba rosaeodora essential oil on different bacterial cultures after $24 \mathrm{~h}$ of treatment.

\begin{tabular}{cccccc}
\hline \multirow{2}{*}{ Antimicrobial assay } & Compounds & \multicolumn{4}{c}{ Bacteria Strain } \\
\cline { 3 - 6 } & & $\begin{array}{c}\text { Escherichia } \\
\text { coli }\end{array}$ & $\begin{array}{c}\text { Staphylococcus Pseudomonas } \\
\text { aureus }\end{array}$ & $\begin{array}{c}\text { Salmonella } \\
\text { aeruginosa }\end{array}$ \\
& A. rosaeodora & $15.0 \pm 0.00$ & $18.0 \pm 0.00$ & $13.0 \pm 0.00$ & $14.0 \pm 0.00$ \\
Inhibition zones $(\mathrm{mm})$ by & linalool & $13.0 \pm 0.00$ & $15.0 \pm 0.00$ & $12.0 \pm 0.00$ & $12.0 \pm 0.00$ \\
disc-diffusion & gentamycin & $14.0 \pm 0.00$ & $20.5 \pm 0.70$ & $17.0 \pm 0.00$ & n.d. \\
& penicillin & n.d. & n.d. & n.d. & $18.5 \pm 0.70$ \\
\hline & A. rosaeodora & $350.0 \pm 0.00$ & $250.0 \pm 0.00$ & $450.0 \pm 0.00$ & $400.0 \pm 0.00$ \\
& linalool & $650.0 \pm 0.00$ & $550.0 \pm 0.00$ & $650.0 \pm 0.00$ & $650.0 \pm 0.00$ \\
MIC $(\mu \mathrm{g} / \mathrm{mL})$ & amoxicillin & $16.0 \pm 0.00$ & $8.0 \pm 0.00$ & n.d. & n.d. \\
& gentamycin & n.d. & $2.0 \pm 0.00$ & n.d. & $8.0 \pm 0.00$ \\
& polymyxin B & n.d. & n.d. & $16.0 \pm 0.00$ & n.d. \\
\hline
\end{tabular}

MIC: minimum inhibitory concentration; n.d.: not determined. Data represents mean \pm standard deviation of experiment realized in triplicate.

\subsection{Antioxidant Activity of A. rosaeodora Essential Oil and Linalol}

Aniba roseadora essential oil and linalool presented antioxidant activity concentrationdependent, as observed in the graph that relates $A$. rosaeodora essential oil and linalool concentration versus the percentage of inhibition of the 2,2-azinobis- (3-ethylbenzothiazoline6-sulfonic acid) (ABTS) radical (Figure 3). The calculated $\mathrm{EC}_{50}$ was $15.46 \mu \mathrm{g} / \mathrm{mL}$ for $A$. rosaeodora essential oil and $6.78 \mu \mathrm{g} / \mathrm{mL}$ for linalool.

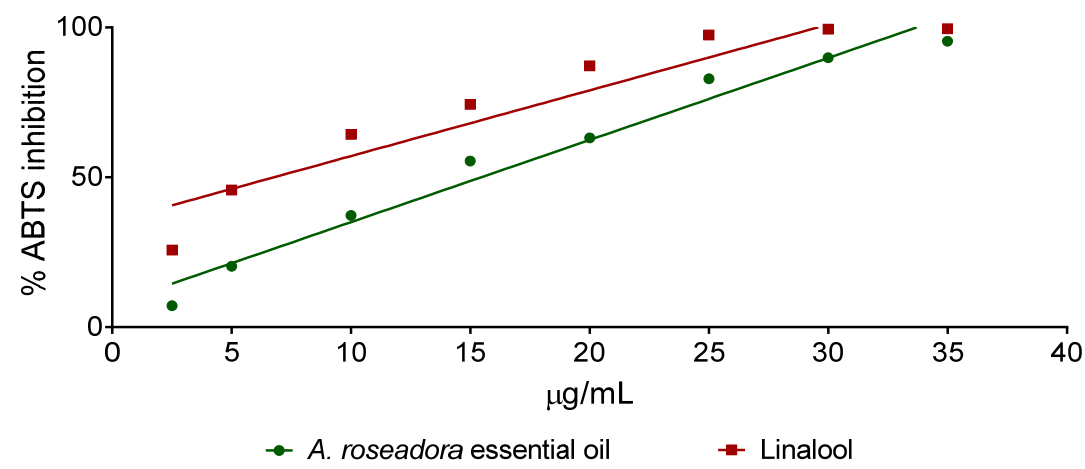

Figure 3. Inhibition of the 2,2-azinobis- (3-ethylbenzothiazoline-6-sulfonic acid) (ABTS) radical by Aniba rosaeodora essential oil and linalool. 


\subsection{Cytotoxicity, Antitrypanosomal Activivy and Selectivity Index of A. rosaeodora Essential Oil and Linalool}

The activity of $A$. rosaeodora essential oil and linalool was evaluated against the epimastigote and intracellular amastigote forms of Trypanosoma cruzi, as well as its cytotoxic effect against mammal cells. Both compounds presented concentration-dependent inhibitory activity against epimastigote and intracellular amastigote forms of T. cruzi (Figure 4). The inhibitory concentration for $50 \%$ of parasites $\left(\mathrm{IC}_{50}\right)$ values for epimastigote forms was lower for A. rosaeodora essential oil than linalool. Analyzing the activity against different forms of the T. cruzi, A. rosaeodora essential oil exhibited $\mathrm{IC}_{50}$ value against epimastigote 6.0-fold higher in comparison to the $\mathrm{IC}_{50}$ against intracellular amastigotes forms. In contrast, linalool was 3.65-fold more effective against $T$. cruzi intracellular amastigote when compared to $A$. rosaeodora essential oil. Both compounds presented higher $\mathrm{IC}_{50}$ values when compared to benznidazole. Cytotoxicity assay revealed that $A$. roseadora essential oil and linalool not showed toxicity for BALB/c peritoneal macrophages even at the highest concentration analyzed $(1000 \mu \mathrm{g} / \mathrm{mL})$. Thus, linalool exhibited higher SI value than $A$. roseadora essential oil (Table 4 ).
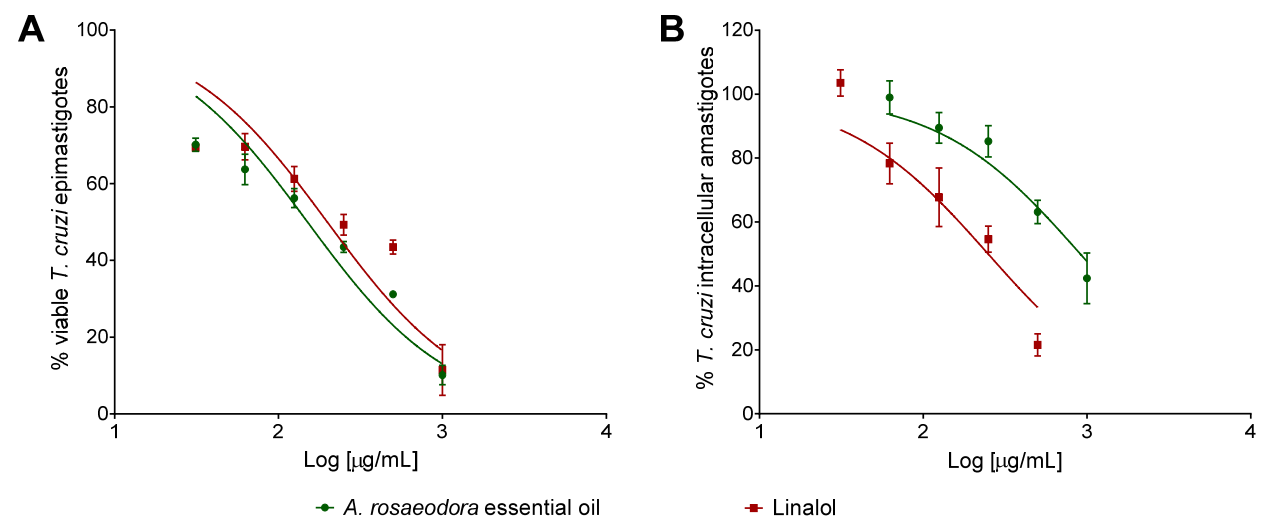

Figure 4. Activity of Aniba rosaeodora essential oil and linalool against Trypanosoma cruzi epimastigote (A) and intracellular amastigote forms (B) after $24 \mathrm{~h}$ of treatment. Data represent media \pm standard deviation of three independent experiment realized in triplicate.

Table 4. BALB/c peritoneal macrophage cytotoxicity, trypanocidal activity and selectivity index of Aniba rosaeodora essential oil and linalool.

\begin{tabular}{ccccc}
\hline \multirow{2}{*}{$\begin{array}{c}\text { Essential oill } \\
\text { Compounds }\end{array}$} & Citotoxicity $\mathrm{CC}_{\mathbf{5 0}}(\boldsymbol{\mu g} / \mathbf{m L})$ & T. cruzi $\mathrm{IC}_{\mathbf{5 0}}(\boldsymbol{\mu g} / \mathrm{mL})$ & \multirow{2}{*}{ SI } \\
\cline { 2 - 4 } & Peritoneal Macrophage & Epimastigote & $\begin{array}{c}\text { Intracellular } \\
\text { Amastigote }\end{array}$ & \\
\hline A. rosaeodora & $>1000$ & $150.5 \pm 1.08$ & $911.6 \pm 1.15$ & $>1.0$ \\
linalool & $>1000$ & $198.6 \pm 1.12$ & $249.6 \pm 1.18$ & $>4.0$ \\
benznidazole & $162.0 \pm 1.11$ & $1.805 \pm 1.13$ & $0.4820 \pm 1.17$ & 336.0 \\
\hline
\end{tabular}

$\mathrm{IC}_{50}$ : inhibitory concentration for $50 \%$ of parasites; $\mathrm{CC}_{50}$ : cytotoxic concentration for $50 \%$ of cells;

SI: selectivity index, obtained from the ratio $\mathrm{CC}_{50} / \mathrm{IC}_{50}$ intracellular amastigote. Data represents mean \pm standard deviation of at least two independent experiments carried out in triplicate.

The parameters of infection analysis (Figure 5) showed that $A$. rosaeodora essential oil treatment displayed significant low number of amastigotes per 100 cells at $1000 \mu \mathrm{g} / \mathrm{mL}$ $(p=0.0001)$ and $500 \mu \mathrm{g} / \mathrm{mL}(p=0.0011)$ (Figure 5A). Linalool showed a low number of amastigotes per 100 cells at $500 \mu \mathrm{g} / \mathrm{mL}(p=0.0001), 250 \mu \mathrm{g} / \mathrm{mL}(p=0.0014)$ and $125 \mu \mathrm{g} / \mathrm{mL}$ $(p=0.0290)$ (Figure 5B). On the other hand, the treatment with A. rosaeodora essential oil and linalool only presented a significant low mean number of amastigotes per infected cells at $1000 \mu \mathrm{g} / \mathrm{mL}(p=0.0398$, Figure $5 \mathrm{C})$ and $500 \mu \mathrm{g} / \mathrm{mL}(p=0.0229$, Figure 5D), respectively. The alterations in intracellular amastigotes of T. cruzi after treatment with $A$. rosaeodora essential oil and linalool are represented in photomicrography images of Figure 5E. 
A

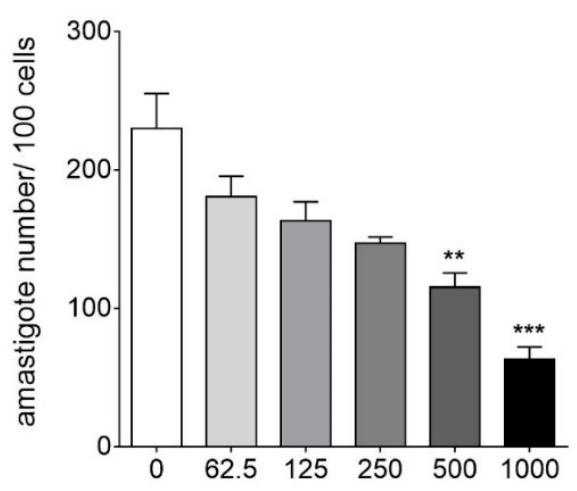

A. rosaeodora essential oil $(\mu \mathrm{g} / \mathrm{mL})$

C

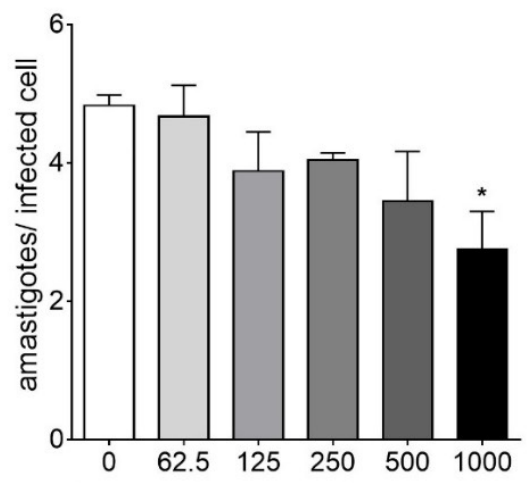

A. rosaeodora essential oil $(\mu \mathrm{g} / \mathrm{mL})$
B

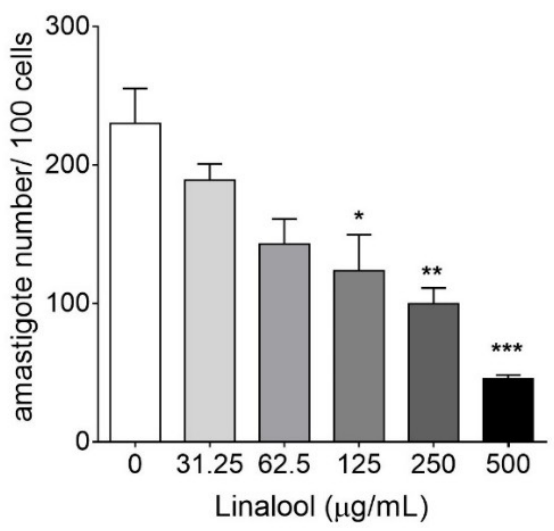

D

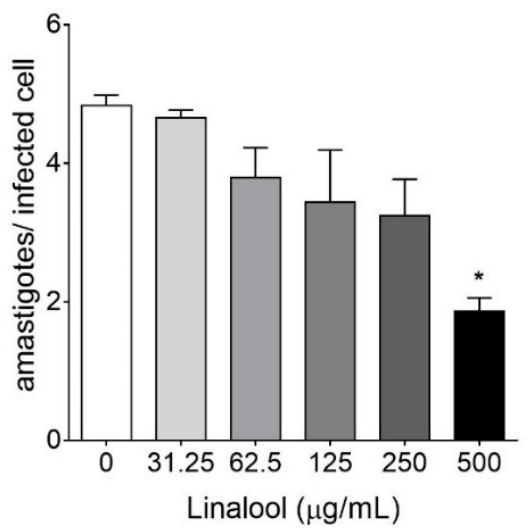

E

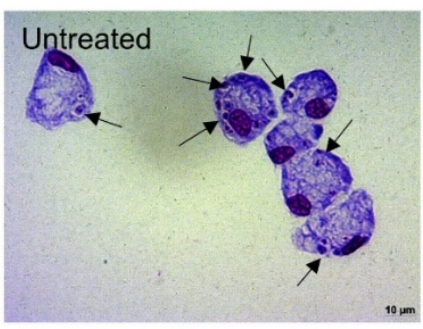

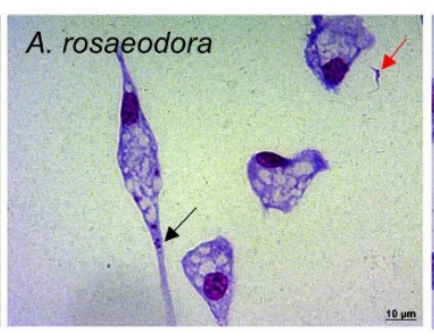

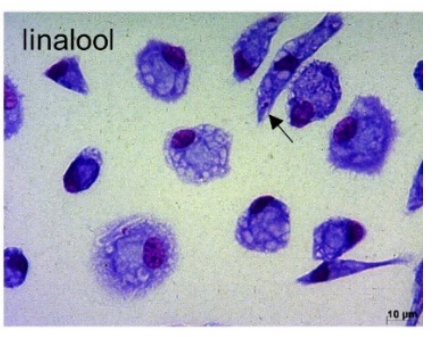

Figure 5. BALB/c peritoneal macrophages infected with Trypanosoma cruzi and treated for $24 \mathrm{~h}$ with Aniba rosaeodora essential oil or linalool. (A-D) Parameters of infection and (E) light microscopy after A. rosaeodora or linalool treatment at 1000 or $500 \mu \mathrm{g} / \mathrm{mL}$ respectively. Intracellular amastigotes inside macrophages (black arrows) and non-internalized parasite (red arrows). The images and data (mean \pm standard deviation) represent two independent experiments performed in quadruplicate. ${ }^{*} p<0.05,{ }^{* *} p<0.01$ and ${ }^{* *} p<0.001$ when compared with untreated infected cells by Kruskal-Wallis and Dunn's multiple comparison test. Giemsa, $40 \times$ objective.

2.5. Nitrite Quantification in T. Cruzi-Infected Peritoneal Macrophages Treated with A. rosaeodora Essential Oil and Linalool

The nitrite quantification in the supernatant of BALB/c peritoneal macrophages showed low nitrite levels in cells treated with $A$. rosaeodora essential oil $(0.150 \pm 0.220 \mu \mathrm{M}$ $\left.\mathrm{NaNO}_{2}, p=0.0259\right)$ and linalool $\left(0.175 \pm 0.146 \mu \mathrm{M} \mathrm{NaNO}_{2}, p=0.0490\right)$ when compared to untreated-unstimulated cells $\left.(1.129 \pm 0.501 \mu \mathrm{M} \mathrm{NaNO})_{2}\right)$. In T. cruzi-stimulated cells, although nitrite levels after treatment with $A$. rosaeodora essential oil $(0.952 \pm 0.779 \mu \mathrm{M}$ $\left.\mathrm{NaNO}_{2}\right)$ and linalool $(1.047 \pm 0.702 \mu \mathrm{M} \mathrm{NaNO} 2)$ were lower than stimulated-untreated cells $(1.347 \pm 0.416 \mu \mathrm{M} \mathrm{NaNO} 2)$, the difference was not statistically significant for both compounds ( $p=0.945$ and $p>0.999$, respectively) (Figure 6). 


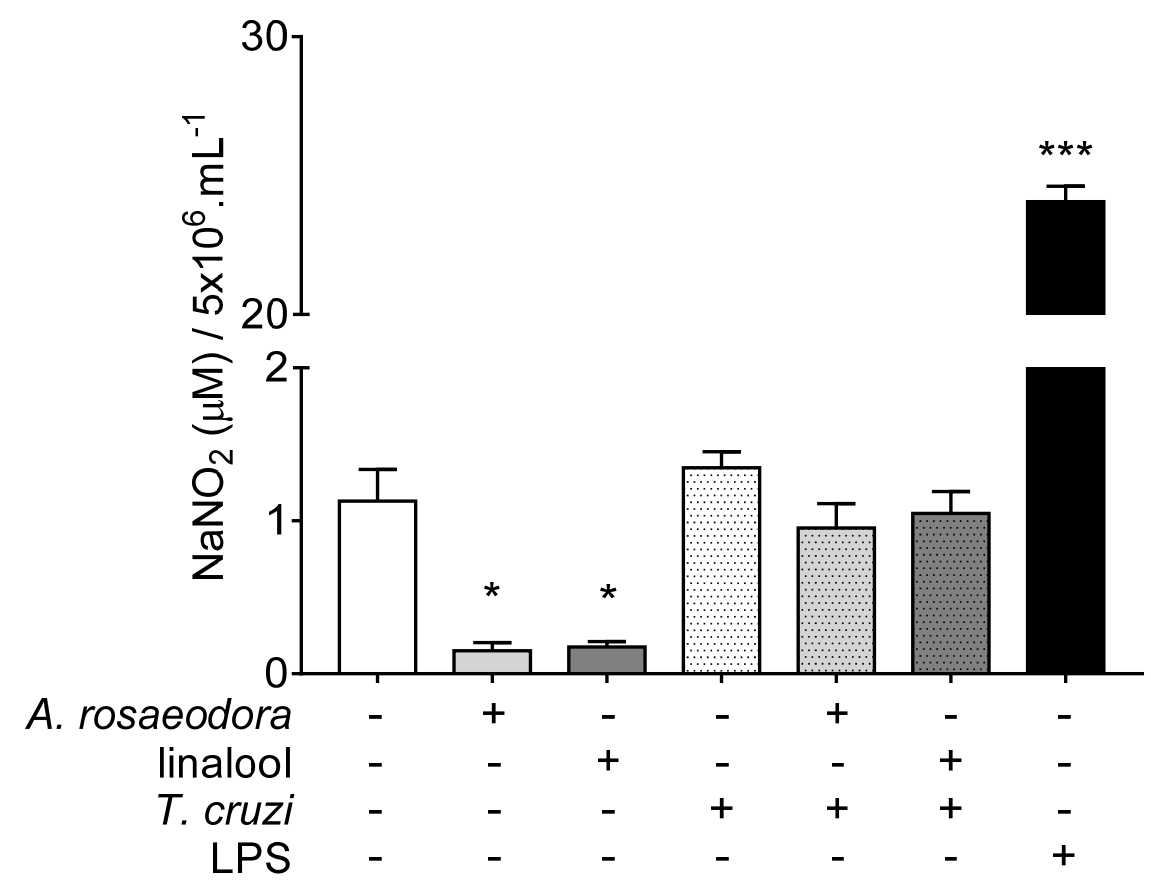

Figure 6. Nitrite quantification in the supernatant of the BALB/c peritoneal macrophage treated with Aniba rosaeodora essential oil $(500 \mu \mathrm{g} / \mathrm{mL})$ or linalool $(125 \mu \mathrm{g} / \mathrm{mL})$, and stimulated or not with Trypanosoma cruzi. Data represents mean \pm standard deviation of experiment realized in sextuplicate; ${ }^{*} p<0.05,{ }^{* * *} p<0.001$ when compared with untreated and unstimulated macrophages by Kruskal-Wallis and Dunn's multiple comparison test.

\section{Discussion}

Essential oil may change depending on the chemical nature of its constituents and can be modified by air, light, heat, water and various impurities of natural origin or from falsifications. The changes can be recognized both by changes in their organoleptic characteristics (aroma, color, taste, transparency, fluidity), as well as the values of their chemical and physical parameters. Thus the density, refractive index, solubility, color and appearance were analyzed and the physical characteristics of the essential oil were similar to the pattern described in previous studies of $A$. rosaeodora [14].

Studies has identified and quantified chemical compounds of $A$. rosaeodora essential oil, revealing that this species has chemotypes similar to essential oil extracted in Belém, state of Pará, Brazil, with linalool $(84.8 \%)$ as the major compound, followed by $\alpha$-terpineol $(2.9 \%)$, geraniol $(1.0 \%)$, benzyl benzoate $(0.6 \%)$ and minimal amounts of monoterpene hydrocarbons and oxygenated sesquiterpenes (9.2\%) [15]. The same was observed in the study of $A$. rosaeodora essential oil extracted in São Paulo, Brazil, where the presence of linalool (81.45\%), trans-linalool oxide (1.19\%), R-terpineol (1.09\%) were observed [16]. Almeida et al. (2013) also reported that linalool is the main compound in essential oil obtained from wood, leaves and branches of the Brazilian rosewood [17].

The disk diffusion test carried out against standard strain bacteria and against bacteria isolated from a marine environment evidenced antibacterial activity, preliminarily. The mixed sensibility observed to the several antibiotics revealed the resistance pattern of marine environment bacteria. The sensibility observed to $A$. rosaeodora essential oil and linalool showed that both compounds have activity against marine environment bacteria used in this study. It is known that the bacterial cell wall influences in an important way on the action of certain antibiotics. The difference between Gram-positive and Gramnegative bacterial walls would be one of the responses to antibiotic resistance between two bacteria [14]. Bacterial resistance is best evidenced in environmental bacteria in the last few years. With the advent of modernization, an increasing amount of antibiotics was released into the environment along with the residues from domestic, industrial, 
agricultural and medical activities. This has ended up generating a selection of antibioticresistant bacteria or genes in the environment, which threatens the efficiency of antibiotics in fighting bacterial infections [18].

The MIC of $A$. rosaeodora essential oil resulted in concentrations lower than linalool. Holetz, et al. (2002) classifies samples that have MIC values below $100 \mu \mathrm{g} / \mathrm{mL}$ with good antibacterial activity; 100 to $500 \mu \mathrm{g} / \mathrm{mL}$ moderate; and 500 to $1000 \mu \mathrm{g} / \mathrm{mL}$ weak above $1000 \mu \mathrm{g} / \mathrm{mL}$ inactive [19]. Following this classification, A. rosaeodora essential oil showed moderate activity, while linalool displayed weak activity. The difference between the activity of both compounds may be related to the synergistic effect of the compounds present in the essential oil of $A$. rosaeodora. A synergistic interaction can be verified between the essential oils of $A$. rosaeodora and Pelargonium graveolens with gentamicin, and a very strong synergistic interaction against Acinetobacter baumannii ATCC 19606 (fractional inhibitory concentration/FIC index $=0.11$ ) [20]. While research conducted with linalool showed low activity against Gram-positive and Gram-negative bacteria. Jabir et al. (2018) found that linalool loaded in gold nanoparticles modified with glutathione (LIN-GNPs) has effective antibacterial activity against Gram-positive bacteria, proving that LIN-GNPs acted on the bacterial cell membrane, in giving up and increasing cell wall permeability and stimulated reactive oxygen species (ROS) production that leads to bacterial nucleic acid damage [21].

Linalool is a compound widely used by the cosmetics industry [22] In the study by Herman et al. (2016) [10], a significant increase in antimicrobial efficacy was observed by the addition of linalool to essential oil, reducing its concentrations in products (cosmetics, medicine), making it possible to obtain its synergistic and additive effects. In addition, several studies have been reported on the commercial availability of oxidized linalool samples possibly causing allergic contact dermatitis [23-25]. Thus, essential oil from $A$. rosaeodora has potential applicability in edible and/or dermatological preparations.

Biological activity may be directly related to phenolic compounds as they are good electron donors and therefore have efficient antioxidant activity among secondary plant metabolites. These compounds are capable of control oxidative damage generated by reactive oxygen species or radicals [26]. We can also classify the antioxidant activity according to the excellent $\left(\mathrm{IC}_{50}<15 \mu \mathrm{g} / \mathrm{mL}\right)$, good $\left(15 \mu \mathrm{g} / \mathrm{mL}<\mathrm{IC}_{50}<50 \mu \mathrm{g} / \mathrm{mL}\right)$, medium $\left(50 \mu \mathrm{g} / \mathrm{mL}<\mathrm{IC}_{50}<100 \mu \mathrm{g} / \mathrm{mL}\right)$, and weak activity $\left(\mathrm{IC}_{50} \geq 100 \mu \mathrm{g} / \mathrm{mL}\right)$. $A$. rosaeodora essential oil antioxidant activity was considered good while the linalool was optimal, corroborating with previous studies that verified excellent antioxidant activity of Aniba species [26].

In traditional medicine, plant essential oils are known as a rich source of secondary metabolites with relevant biological activities, as an alternative in antiparasitic therapy $[27,28]$. The trypanocidal activity of essential oils of Aniba genus was described in the literature $[14,29]$. Currently, the drugs available for the treatment of Chagas disease are benznidazole and nifurtimox, which have limited efficacy, serious adverse effects and have been in use since the late 1960s [30]. Thus, in an attempt to search for new therapeutic alternatives for Chagas disease, we report the effect of $A$. rosaeodora essential oil and its main component linalool in the growth of epimastigote and intracellular amastigote forms of T. cruzi.

In the present study, A. rosaeodora essential oil showed activity against epimastigote forms. Literature data showed anti-T. cruzi activity in vitro in extracts and substances of different species of the Aniba genus of plants collected in the Amazon [29], with promising antileishmanial activity [14]. To understand whether linalool is responsible for the inhibitory activity, an analysis of linalool against epimastigote was performed. The results showed an inhibitory effect close to the values of $A$. rosaeodora essential oil. Therefore, it is worth inferring that the inhibitory effect of the essential oil occurs due to the high concentration of linalool, or due to a possible synergistic and/or additive effect of the constituents of the essential oil acting as trypanocidal agents [31]. 
Previous data demonstrated that the $\mathrm{IC}_{50} / 24 \mathrm{~h}$ for linalool was $162.5 \mu \mathrm{g} / \mathrm{mL}$ for epimastigotes and $264 \mu \mathrm{g} / \mathrm{mL}$ for T. cruzi trypomastigotes (Y strain) [32], corroborating with data presented in this study. However, linalool had a potent trypanocidal effect against the trypomastigote form of $T$. cruzi (clone Dm28c) derived from cells, with $\mathrm{IC}_{50} / 24 \mathrm{~h}$ of $306 \mathrm{ng} / \mathrm{mL}$, indicating that different forms and/or origin and different strains may differ in their susceptibility to essential oil derivatives [33].

The search for new therapeutic drugs requires conditions that simulate the environment found by the parasite-cell interaction, therefore, the assay against intracellular amastigote forms of tripanosomatids may represent ideal conditions, with macrophages playing an important role in the evaluation of drug-mediated toxicity [34]. Thus, it was evaluated whether $A$. rosaeodora essential oil and linalool could inhibit T. cruzi intracellular amastigote. However, the inhibitory effect was observed only when infected cells were treated with linalool although in high concentration, while $A$. rosaeodora essential oil presented activity at an even higher concentration.

Piper aduncum essential oil (PaEO), with nerolidol (25.22\%) and linalool (13.42\%) as main constituents, effectively inhibits the intracellular survival/replication of $\mathrm{T}$. cruzi amastigotes. PaEO at a concentration of $12.5 \mu \mathrm{g} / \mathrm{mL}$ decreased the rate of T. cruzi amastigote infection by $71.5 \%$, with an $\mathrm{IC}_{50} / 24 \mathrm{~h}$ of $9 \mu \mathrm{g} / \mathrm{mL}$. As linalool showed trypanocidal activity, with $\mathrm{IC}_{50} / 24 \mathrm{~h}$ of $306 \mathrm{ng} / \mathrm{mL}$ against trypomastigotes [33], it is possible to infer that activity against intracellular amastigote forms it is possibly due to linalool presence. In addition, previous data demonstrated that at low concentrations of purified linalool derived from the Croton cajucara essential oil, the number of parasites internalized in the macrophages decreased (treated before and after the interaction). On the other hand, no cytotoxic effects of essential oil and linalool were observed in peritoneal macrophages of Swiss mice and Vero cells [35]. As in our study, A. rosaeodora essential oil and linalool not exhibited cytotoxicity against peritoneal macrophages in the concentration range under analysis. As a result, linalool showed a select activity to the parasites when compared to mammalian cells [14].

Literature data with L. infantum chagasi determined that the post-interaction treatment with linalool has antiparasitic activity against intracellular amastigotes, inducing a decrease in the number of parasites within the macrophages [36]. In the same study, it was observed that linalool is capable of providing a drastic change in oxygen consumption, probably related to mitochondrial dysfunction. P. aduncum essential oil rich in linalool induced mitochondria dysfunction altering the mitochondrial membrane potential of the T. cruzi epimastigote [33]. Mitochondrial alterations as swelling and important changes in the organization of nuclear and kinetoplastic chromatins were observed by electron microscopy when L. amazonensis parasites were treated with C. cajucara essential oil [35]. Linalool may interfere with the integrity of protozoan mitochondria, however, further studies are needed to elucidate the mechanism involved in the trypanocidal activity observed in our study.

An indirect mechanism involved with antitrypanosomal activity is related with macrophage activation, particularly the nitric oxide (NO) induction. The NO-mediation directly kills T. cruzi in vitro [37]. Thus, we carried out an analysis of the nitrite quantification of T. cruzi-stimulated peritoneal macrophages treated with A. rosaeodora essential oil or linalool. However, a significant decrease in nitrite levels was observed in cells nonstimulated with $T$. cruzi and treated with $A$. rosaeodora essential oil or linalool. Reactive oxygen species decrease was also observed in cancer cells lines treated with $A$. rosaeodora essential oil, inhibiting apoptosis in these cells [13].

Otherwise, in T. cruzi-stimulated cells the treatment with A. rosaeodora essential oil or linalool did not significantly decrease nitrite levels. Linalool has a known anti-inflammatory activity [38] and inhibits NO formation in vitro [39], but interestingly, an in vitro experiment of macrophages treated with linalool $(250$ or $350 \mu \mathrm{g} / \mathrm{mL}$ ) for $24 \mathrm{~h}$ before or after interactions with the Leishmania infantum was also not associated with any difference in NO production [36]. The inhibition of NO production observed in macrophages treated with $A$. 
rosaeodora essential oil and linalool, although it is not associated with antitrypanosomal activity, is an interesting finding that should be better elucidated in further studies.

\section{Materials and Methods}

\subsection{Reagents}

Anhydrous sodium sulfate, ethanol, ethyl acetate, dimethyl sulfoxide (DMSO), eugenol, 2,2'-azino-bis(3-ethylbenzothiazoline-6-sulfonic acid) diammonium salt (ABTS), penicillin, streptomycin, N-benzyl-2-nitro-1H-imidazole-1-acetamide (Benznidazole), Brewer thioglycolate medium, RPMI 1640 medium, 3-(4,5-Dimethyl-2-thiazolyl)-2,5-diphenyl-2Htetrazolium bromide (MTT), sulfanilamide, $\mathrm{H}_{3} \mathrm{PO}_{4}, \mathrm{~N}-(1$-naphthyl)ethylenediamine and sodium nitrite were purchased from Sigma, St Louis, MO, USA. Giemsa's azur-eosinmethylene blue, Brain Heart Infusion broth, Mueller-Hinton agar and Mueller-Hinton broth were purchased from MERK, Darmstadt, Germany. The other bacteria culture medium were purchased from BD, Becton Dickinson, Franklin Lakes, NJ, USA. API ${ }^{\circledR} 20$ E system was purchased from bioMérieux, Durham, NC, USA. Fetal bovine serum (FBS) was purchased from Gibco, Gaithersburg, MD, USA.

\subsection{Plant Material}

Authentic samples of the A. rosaeodora species were obtained from three trees cultivated at the Adolpho Ducke Forest Reserve, Highway AM-010, km 26 (latitude -2.908185, longitude -59.975457), Manaus, Brazil. Leaves and thin branches were harvested with a trimmer from the treetops in the dry season, March 2017. The taxonomic identification was undertaken by the Herbarium of the Department of Botany of the Universidade Federal do Amazonas, registry number 5982. The leaves were selected and dried in an oven at $37^{\circ} \mathrm{C}$ for $48 \mathrm{~h}$ and sprayed in an electric knife mill at the Food and Water Quality Control Laboratory of the Federal University of Maranhão.

\subsection{Essential Oil Extraction}

The extraction of the essential oil of $A$. rosaeodora was carried out with $100 \mathrm{~g}$ of dried leaves from thin branches diluted in water in the proportion of 1:10 by hydrodistillation using the Clevenger system for $3 \mathrm{~h}$ at $100^{\circ} \mathrm{C}$. The essential oil collected were dried with anhydrous sodium sulfate $\left(\mathrm{Na}_{2} \mathrm{SO}_{4}\right)$ and the final volume found was used to determine the yield through the mass/volume ratio by measuring the density. Mass/volume ratios were calculated from the mass $(\mathrm{g})$ of the initial vegetal material and the volume $(\mathrm{mL})$ of essential oil obtained after extraction. The essential oil samples were kept at $25^{\circ} \mathrm{C}$ and then weighed. For the verification of biological activity in vitro, the essential oil and the reference drugs were diluted in DMSO and subsequently made serial dilutions in an appropriate culture medium until reaching a final concentration below $1 \%$ DMSO.

\subsection{Physical-Chemical Analysis of Essential Oil}

Physical-chemical analyzes performed on A. rosaeodora essential oil were: density, measured with a glass pycnometer; refractive index, calculated with an ABBE 2WAJ refractometer (PCE Instruments, Southampton, UK); the color and appearance, that were visually verified by three different people; and the determination of solubility, carried out through the ratio of 1:1 of oil and $70 \%$ ethanol until its complete solubilization.

\subsection{Gas Chromatography-Mass Spectrometry (GC-MS)}

The standard used in the development of the analytical methodology was linalool. Standard solutions of monoterpenes were prepared by dilution in absolute ethyl alcohol and chloroform at different concentrations. The essential oil of $A$. rosaeodora was solubilized in ethyl acetate and was analyzed by a gas chromatograph Shimadzu QP 5000 (Shimadzu Corp., Kyoto, Japan), a column used with a capillary ZB-5 ms (5\% phenyl arylene 95\% dimethylpolysiloxane) coupled to $70 \mathrm{eV}(40-500 \mathrm{Da}) \mathrm{HP} 5 \mathrm{MS}$ electronic impact detector with a transfer temperature of $280^{\circ} \mathrm{C}$. In the analysis, $0.3 \mu \mathrm{L}$ of ethyl acetate and helium 
gas $(99.99 \%)$ were injected at a temperature of $280^{\circ} \mathrm{C}$, using a split mode $(1: 10)$ with an initial temperature gradient of 40 to $300{ }^{\circ} \mathrm{C} \cdot \mathrm{min}^{-1}$, with a chromatographic run that lasted $30 \mathrm{~min}$.

\subsection{Bacteria from Marine Enviroment}

Bacteria strains isolated from the marine environment Aeromonas caviae, Aeromonas hydrophila, Enterococcus faecalis, Klebsiella pneumoniae and Providencia stuartii were gently provided by the Laboratory of Microbiology of the Water Quality Control Program at the Federal University of Maranhão. Water samples were aseptically collected from approximately $30 \mathrm{~cm}$ below the water surface of the Jansen lagoon, Maranhão Brazil (latitude -2.499629 , longitude -44.301211). Then, the samples were transported to the Microbiology Laboratory of the Federal University of Maranhão in isothermal boxes containing ice to perform the identification. To Aeromonas isolation, successive decimal dilutions of water samples $\left(10^{-1}\right.$ to $\left.10^{-7}\right)$ were prepared in alkaline peptone water (APA), with subsequent distribution of $1 \mathrm{~mL}$ aliquots in five series of five tubes containing tryptic soy broth (TSB Broth) and $0.1 \mathrm{~mL}$ in plates containing the selective medium, agar gelatin phosphate salt (GSP Agar) (duplicates), both with $20 \mu \mathrm{g} / \mathrm{mL}$ of ampicillin, an antibiotic used as an inhibitor of the accompanying microbiota of Aeromonas. Colonies suspected of being Aeromonas were seeded in tilted BD trypticase soy agar (TSA agar) tubes, followed by incubation at $28{ }^{\circ} \mathrm{C}$ for $24 \mathrm{~h}$. After, the cultures on TSA agar were subjected to biochemical tests of oxidase, catalase, gas production from glucose for species identification, indole production, $\mathrm{O} / 129$ resistance, amino acid decarboxylation (test on triple sugar agar and iron-TSI agar), motility: nitrate reduction, esculine hydrolysis, Voges-Proskauer (VP) assay, carbohydrate fermentation and growth at 3\% and 6\% sodium chloride. To Enterobacteriaceae isolation and identification of Klebsiella pneumoniae and Providencia stuartii in the water samples, initially, $25 \mathrm{~mL}$ of each sample were homogenized in $225 \mathrm{~mL}$ of brain and heart infusion broth (BHI broth) and incubated in a bacteriological oven at $37^{\circ} \mathrm{C}$ for three hours. After the incubation period, the entire inoculum was transferred to $250 \mathrm{~mL}$ of broth for Escherichia coli and incubated at $37^{\circ} \mathrm{C}$ for $24 \mathrm{~h}$. Isolation was performed using selective and differential media, methylene blue eosin agar (EMB agar) and MacConkey sorbitol agar (MCS agar). For the identification of the species, initially five colonies were selected from the selective culture media, small colonies with metallic green or black without gloss in EMB agar and those of intense pink color (positive sorbitol) and yellow (negative sorbitol) in MCS agar. Then, the colonies were isolated in tubes containing TSA agar inclined with subsequent incubation at $37^{\circ} \mathrm{C}$ for $24 \mathrm{~h}$. Biochemical identification was performed using conventional tests: indole, simmons citrate, methyl red, VP, malonate, carbohydrate fermentation-sorbitol, rhamnose, mannitol, arabinose, inositol and raffinose, decarboxylation of amino acids lysine and ornithine, motility and $\mathrm{H}_{2} \mathrm{~S}$ production in sulfide indole motility (SIM) agar [40] and by the $\mathrm{API}^{\circledR} 20 \mathrm{E}$ system. For Enterococcus research, $9 \mathrm{~mL}$ of each sample were diluted in $90 \mathrm{~mL}$ of buffered peptide water and incubated for $24 \mathrm{~h} / 35^{\circ} \mathrm{C}$. Subsequently dilutions $\left(10^{-1}\right.$ to $\left.10^{-7}\right)$ and the highest dilution were plated on $\mathrm{M}$-Enterococcus agar and incubated at $35^{\circ} \mathrm{C}$ for $48 \mathrm{~h}$. Brick red colonies were inoculated on TSI agar. Tubes that showed suggestive characteristics were analyzed by acid ramp, acid-base, $\mathrm{H}_{2} \mathrm{~S}(-)$, catalase, oxidase, $6 \% \mathrm{NaCl}$, glucose and esculin tests, and by the API ${ }^{\circledR}$ 20 E system.

\subsection{Bacterial Strains and Culture Conditions}

To perform the preliminary antimicrobial tests, the standard strains Escherichia coli (Migula) Castellani and Chalmers (ATCC ${ }^{\circledR} 25922^{\mathrm{TM}}$ ), Staphylococcus aureus subsp. aureus Rosenbach (ATCC ${ }^{\circledR} 12600^{\mathrm{TM}}$ ), Pseudomonas aeruginosa (Schroeter) Migula (ATCC ${ }^{\circledR} 27853^{\mathrm{TM}}$ ) and Salmonella enterica subsp. enterica (ex Kauffmann and Edwards) Le Minor and Popoff serovar Choleraesuis (ATCC ${ }^{\circledR} 12011^{\mathrm{TM}}$ ) were used. The tests were carried out at the Microbiology Laboratory of the Federal University of Maranhão. The strains were grown in BHI broth for $24 \mathrm{~h}$ at $37^{\circ} \mathrm{C}$ and the inoculum was adjusted to a cell concentration of $10^{8}$ colony 
forming unit (CFU)/mL following the MacFarland scale, recommended by the Clinical and Laboratory Standards Institute [41].

\subsection{Antimicrobial Assays}

During the preliminary test of diffusion in solid medium, $100 \mu \mathrm{L}$ of inoculum of each bacterium sown on Mueller-Hinton agar plates were used, and on the agar surface, a paper disc impregnated with $50 \mu \mathrm{L}$ of essential oil of $A$. rosaeodora, standard linalool or reference drugs were added; then the plates were incubated at $35^{\circ} \mathrm{C}$ and after $24 \mathrm{~h}$ the inhibition zone was measured with a millimeter rule [42]. The MIC was also performed according to the broth dilution methodology performed in triplicate with the same bacteria used in the diffusion tests in solid medium [41]. Initially, serial dilutions were performed resulting in concentrations of 5-1000 $\mu \mathrm{g} / \mathrm{mL}$ of $A$. rosaeodora essential oil, linalool or reference drugs and transferred to a test tube containing Mueller-Hinton broth. To each concentration, $100 \mu \mathrm{L}$ of the microbial suspension containing $1.5 \times 10^{8} \mathrm{CFU} / \mathrm{mL}$ were added and subsequently incubated at $35^{\circ} \mathrm{C}$ for $24 \mathrm{~h}$. It was also reserved control of broth sterility and bacterial growth. After the incubation period, the MIC was determined, being defined as the lowest concentration that visibly inhibited bacterial growth (absence of visible turbidity). To confirm growth inhibition, the broth was subjected to the microbial seeding test of the inoculum on the surface of the plate-count agar.

\subsection{Antioxidant Assay}

Antioxidant activity was assessed using a reaction mixture of 2,2-azinobis- (3ethylbenzothiazoline-6-sulfonic acid) (ABTS) at $3840 \mu \mathrm{g} / \mathrm{mL}$ with $88 \mu \mathrm{L}$ of $37,840 \mu \mathrm{g} / \mathrm{mL}$ potassium persulfate solution left in the dark at room temperature for $16 \mathrm{~h}$ giving rise to the ABTS radical which was diluted in ethanol to obtain an absorbance of 0.7 to $734 \mathrm{~nm}$. The results were obtained in a dark environment, in which $30 \mu \mathrm{L}$ of each concentration of essential oil (200 to $15 \mu \mathrm{g} / \mathrm{mL}$ ) and eugenol (90 to $5 \mu \mathrm{g} / \mathrm{mL}$ ) was transferred in test tubes containing $3.0 \mathrm{~mL}$ of the cation radical ABTS and homogenized on a tube shaker, and after $6 \mathrm{~min}$ the absorbance of the reaction mixture was read on a spectrophotometer at a length of $734 \mathrm{~nm}$ [43]. The analyses were carried out in triplicates and the determination of the activity was demonstrated as percentage of inhibition (\% I) of the ABTS radical cation according to the equation: \% inhibition = (absorbance of the solution of the radical ABTSabsorbance of the sample)/(solution of ABTS absorbance radical) $\times 100$ [44]. We also verified the efficient concentration or $\mathrm{EC} 50 \%$ that represents the concentration necessary to sequester $50 \%$ of the ABTS root. The essential oil will be considered active when it has an EC50 $<500 \mu \mathrm{g} / \mathrm{mL}[45]$.

\subsection{Parasites}

Parasite cultures employed in this study were Trypanosoma cruzi (SC2005 strain). Trypomastigote forms were obtained from Vero cells infected and used to infect the macrophages. Epimatigote forms were originated from the suspension of cell culture trypomastigotes in $3 \mathrm{~mL}$ of liver infusion tryptose (LIT) medium supplemented with $10 \%$ fetal bovine serum (FBS), $100 \mathrm{U} / \mathrm{mL}$ of penicillin and $100 \mu \mathrm{g} / \mathrm{mL}$ of streptomycin), and incubated in an oven at $28{ }^{\circ} \mathrm{C}$ until complete differentiation of parasites.

\subsection{Anti-Epimastigote Assay}

Epimastigote forms of T. cruzi, from a 2- to 4-day-old culture were incubated for $24 \mathrm{~h}$ in the absence or in the presence of different concentrations $(1000-15.625 \mu \mathrm{g} / \mathrm{mL})$ of $A$. rosaeodora essential oil or linalool, obtained by serial dilutions (1:2), at a final volume of $100 \mu \mathrm{L}$ per well. The controls were identified as blank (wells without parasites), untreated control (parasites and DMSO 1\%) and reference drug (benznidazole). Incubation took place in a 96-wells plate, in a BOD incubator at $28{ }^{\circ} \mathrm{C}$ in LIT medium using a parasite concentration of $10^{6}$ promastigotes $/ \mathrm{mL}$. After $24 \mathrm{~h}$, with the aid of the Neubauer chamber and light microscopy [46], viability was evaluated by counting parasites and the results 
were used to calculate the $\mathrm{IC}_{50}$ (50\% inhibition of parasite growth) following the formula: $\mathrm{IC}_{50}=($ sample counting $) /($ control counting $) \times 100[47]$.

\subsection{Animals and Ethical Statements}

BALB/c female mice from 4 to 6 weeks of age were purchased from the Institute of Science and Technology in Biomodels of the Institute of Science and Technology in Biomodels. All procedures were performed in accordance with the National Council for the Control of Animal Experimentation National Council for Animal Experimentation Control-CONCEA) and approved by the Ethics Committee on Animal Care and Utilization (CEUA/IOC-L018/2018).

\subsection{Peritoneal Macrophage Collection and Culture}

Peritoneal macrophages from BALB/c mice were collected after elicited with $3 \mathrm{~mL}$ $3 \%$ Brewer thioglycollate medium broth injection for $72 \mathrm{~h}$, and maintained in RPMI 1640 medium supplemented with $10 \% \mathrm{FBS}, 100 \mathrm{U} / \mathrm{mL}$ of penicillin and $100 \mu \mathrm{g} / \mathrm{mL}$ of streptomycin, overnight at $37{ }^{\circ} \mathrm{C}$ and $5 \% \mathrm{CO}_{2}$.

\subsection{Cytotoxicity Assay}

Peritoneal macrophages $\left(5 \times 10^{5}\right.$ cells $\left./ \mathrm{mL}\right)$ were cultured in 96-well plates with different concentrations, obtained by serial dilutions (1:2), of $A$. rosaeodora essential oil or linalool $(1000-7.8 \mu \mathrm{g} / \mathrm{mL})$ or benznidazole $(200-0.78 \mu \mathrm{g} / \mathrm{mL})$ up to a final volume of $100 \mu \mathrm{L}$ per well. The controls were categorized as blanks (wells with culture medium without cells), untreated control (cells and DMSO 1\%) and reference drug (benznidazole). After $72 \mathrm{~h}$, the cell viability was analyzed by the MTT colorimetric method [48]. Absorbance was measured in a spectrophotometer at $540 \mathrm{~nm}$ wavelength. The concentration inhibiting 50\% of cell growth $\left(\mathrm{CC}_{50}\right)$ was calculated following the formula: $\mathrm{CC}_{50}=$ (sample absorbanceblank absorbance)/(control absorbance-blank absorbance) $\times 100$ [49].

\subsection{Activitiy Against Intracellular Amastigotes and Selectivity Index (SI)}

BALB/c peritoneal macrophages cultured in 24-well plates $\left(5 \times 10^{5}\right.$ cells/well), with coverslips, were infected with trypomastigote forms of $T$. cruzi, obtained from cultured Vero cells, using the ratio of parasite/cell 10:1, at $37^{\circ} \mathrm{C}$ and $5 \% \mathrm{CO}_{2}$ for $6 \mathrm{~h}$. After incubation, well plates were washed with phosphate-buffered saline (PBS, pH 7.2) to remove the noninternalized parasites. The infected cells were treated with different concentrations of $A$. rosaeodora essential oil or linalool (1000-31.25 $\mathrm{gg} / \mathrm{mL})$, or benzonidazole $(100-6.25 \mu \mathrm{g} / \mathrm{mL})$ for $24 \mathrm{~h}$. The amastigotes couting by analysis of light microscopy were carried out to determine the $\mathrm{IC}_{50}$ calculation. Selectivity index were obtained from the relationship of macrophage cytotoxicity and antiamastigote activity. Parameters of infection analysis were performed according to Teles et al. [50].

\subsection{Nitrite Quantification}

BALB /c peritoneal macrophages $\left(5 \times 10^{6}\right.$ cells $\left./ \mathrm{mL}\right)$ was treated with $A$. rosaeodora essential oil $(500 \mu \mathrm{g} / \mathrm{mL})$ or linalool $(250 \mu \mathrm{g} / \mathrm{mL})$, and either stimulated or not stimulated with $T$. cruzi trypomastigotes $\left(5 \times 10^{7}\right.$ parasites $\left./ \mathrm{mL}\right)$ for $48 \mathrm{~h}$. Nitrite quantification of the supernatant of the cells was performed with Griess reagent. Briefly, $50 \mu \mathrm{L}$ of culture supernatant and $50 \mu \mathrm{L}$ of Griess reagent $\left(25 \mu \mathrm{L}\right.$ of sulfanilamide $1 \%$ in $2.5 \% \mathrm{H}_{3} \mathrm{PO}_{4}$ solution and $25 \mu \mathrm{L}$ of N-(1-naphthyl)-ethylenediamine $0.1 \%$ solution) were added in 96 -well plates. After incubation in a dark environment for $10 \mathrm{~min}$, absorbance was obtained at $570 \mathrm{~nm}$ on the spectrophotometer. The nitrite values were obtained from the standard curve of sodium nitrite $(100-1.5 \mu \mathrm{M})$ [51].

\subsection{Statistical Analysis}

The numerical results from at least two independent assays were expressed as mean \pm standard deviation and the $\mathrm{IC}_{50}$ and $\mathrm{CC}_{50}$ determination were performed with the Graph- 
Pad Prism 7.00 software package (GraphPad Software, San Diego, CA, USA). KruskalWallis and Dunn's multiple comparison test was used to analyze the data and the difference at $p<0.05$ was considered significant.

\section{Conclusions}

The essential oil of $A$. rosaeodora showed activity against all the strains tested, with a lower minimum inhibitory concentration being observed for S. aureus. An efficient antioxidant activity of the essential oil was evidenced by the ABTS radical discoloration technique, fully inhibiting the radical in relatively low concentrations. These results point to an important potential for use as an antimicrobial and antioxidant agent. The antitrypanosomal activity of $A$. rosaeodora essential oil and linalool were observed at high concentrations against epimatigote forms, and even higher against intracellular amastigotes of $T$. cruzi. Both A. rosaeodora essential oil and linalool reduced nitrite levels in unstimulated cells revealing a potential effect in NO production. These data revealed the pharmacological potential of the A. rosaeodora essential oil and linalool, which encourage further studies.

Author Contributions: Conceptualization, A.M.T., J.V.S.-S., A.N.M. and F.A.-S.; methodology, A.M.T., J.V.S.-S., J.M.P.F. and S.C.M.; formal analysis, A.M.T., J.V.S.-S., V.E.M.F., S.C.M. and F.A.-S.; resources, K.d.S.C., A.L.A.-S., A.N.M., V.E.M.F. and F.A.-S.; data curation, A.M.T., J.V.S.-S., A.N.M., S.C.M., V.E.M.F. and F.A.-S.; writing-original draft preparation, A.M.T., J.V.S.-S. and F.A.-S.; writing-review and editing, A.M.T., J.V.S.-S., K.d.S.C., A.L.A.-S., A.N.M., V.E.M.F., S.C.M. and F.A.-S.; visualization, J.M.P.F., V.E.M.F. and F.A.-S.; supervision, A.N.M., V.E.M.F. and F.A.-S.; project administration, K.d.S.C., A.L.A.-S., A.N.M., V.E.M.F. and F.A.-S.; funding acquisition, K.d.S.C., A.L.A.-S., A.N.M., V.E.M.F. and F.A.-S. All authors have read and agreed to the published version of the manuscript.

Funding: This research was funded by the Coordination for the Improvement of Higher Education Personnel (Coordenação de Aper feiçoamento de Pessoal de Nível Superior do Brazil—CAPES) [grant number Finance Code 001]; and the Carlos Chagas Filho Foundation for Research Support of the State of Rio de Janeiro (Fundação Carlos Chagas Filho de Amparo à Pesquisa do Estado do Rio de JaneiroFAPERJ) [grant number E-26/010.001759/2019]. The APC was funded by Oswaldo Cruz Institute (Instituto Oswaldo Cruz-IOC). Fernando Almeida-Souza is postdoctoral researcher fellow of CAPES [grant number 88887.363006/2019-00]. Dra. Ana Lucia Abreu-Silva is research productivity fellow of National Scientific and Technological Development Council (Conselho Nacional de Desenvolvimento Científico e Tecnológico-CNPq) [grant number 309885/2017-5].

Institutional Review Board Statement: The experiments with animals were conducted in accordance with the guidelines for experimental procedures of the Conselho Nacional de Controle de Experimentação Animal (the National Council for the Control of Animal Experimentation) (CONCEA) and approved by the Comissão de Ética no Uso de Animais (the Animal Research Ethics Committee) of the Instituto Oswaldo Cruz (CEUA-IOC/FIOCRUZ), License n ${ }^{\circ}$ L018/2018.

Informed Consent Statement: Not applicable.

Data Availability Statement: All datasets presented in this study are included in the article.

Conflicts of Interest: The authors declare no conflict of interest.

\section{References}

1. Chandra, H.; Bishnoi, P.; Yadav, A.; Patni, B.; Mishra, A.P.; Nautiyal, A.R. Antimicrobial Resistance and the Alternative Resources with Special Emphasis on Plant-Based Antimicrobials-A Review. Plants 2017, 6, 16. [CrossRef] [PubMed]

2. Huang, T.H.; Kota, B.P.; Razmovski, V.; Roufogalis, B.D. Herbal or natural medicines as modulators of peroxisome proliferatoractivated receptors and related nuclear receptors for therapy of metabolic syndrome. Basic Clin. Pharmacol. Toxicol. $2005,96$. [CrossRef] [PubMed]

3. Orchard, A.; van Vuuren, S. Commercial Essential Oils as Potential Antimicrobials to Treat Skin Diseases. Evid. Based Complementary Altern. Med. Ecam 2017, 2017. [CrossRef]

4. Morais, M.C.; Souza, J.V.; da Silva Maia Bezerra Filho, C.; Dolabella, S.S.; Sousa, D.P. Trypanocidal Essential Oils: A Review. Molecules 2020, 25, 4568. [CrossRef]

5. Maia, J.G.S.; Andrade, E.H.A.; Couto, H.A.R.; Silva, A.C.M.; Marx, F.; Henke, C. Plant sources of amazon rosewood oil. Quimica Nova 2007, 30, 1906-1910. [CrossRef]

6. May, P.H.; Barata, L.E.S. Rosewood exploitation in the Brazilian Amazon: Options for sustainable production. Econ. Bot. 2004, 58, 257-265. [CrossRef] 
7. Maia, J.G.S.; Zoghbi, M.G.B.; Andrade, E.H.A. Essential Oils of Aeollanthus suaveolens Matt. ex Spreng. J. Essent. Oil Res. 2003, 15, 86-87. [CrossRef]

8. Maia, J.G.S.; Andrade, E.H.A. Database of the Amazon aromatic plants and their essential oils. Química Nova 2009, 32, 595-622. [CrossRef]

9. Pattnaik, S.; Subramanyam, V.R.; Bapaji, M.; Kole, C.R. Antibacterial and antifungal activity of aromatic constituents of essential oils. Microbios 1997, 89, 39.

10. Herman, A.; Tambor, K.; Herman, A. Linalool Affects the Antimicrobial Efficacy of Essential Oils. Curr. Microbiol. 2016, 72, 165-172. [CrossRef]

11. Seol, G.H.; Kang, P.; Lee, H.S.; Seol, G.H. Antioxidant activity of linalool in patients with carpal tunnel syndrome. BMC Neurol. 2016, 16. [CrossRef] [PubMed]

12. Bero, J.; Kpoviessi, S.; Quetin-Leclercq, J. Anti-Parasitic Activity of Essential Oils and their Active Constituents against Plasmodium, Trypanosoma and Leishmania. Nov. Plant Bioresour. 2014, 455-469. [CrossRef]

13. Soeur, J.; Marrot, L.; Perez, P.; Iraqui, I.; Kienda, G.; Dardalhon, M.; Meunier, J.R.; Averbeck, D.; Huang, M.E. Selective cytotoxicity of Aniba rosaeodora essential oil towards epidermoid cancer cells through induction of apoptosis. Mutat. Res. 2011, 718. [CrossRef]

14. Da Silva, Y.C.; Silva, E.M.S.; Fernandes, N.S.; Lopes, N.L.; Orlandi, P.P.; Nakamura, C.V.; Costa, E.V.; da Veiga Junior, V.F. Antimicrobial substances from Amazonian Aniba (Lauraceae) species. Nat. Prod. Res. 2019, 1-4. [CrossRef]

15. Sampaio Lde, F.; Maia, J.G.; de Parijos, A.M.; de Souza, R.Z.; Barata, L.E. Linalool from rosewood (Aniba rosaeodora Ducke) oil inhibits adenylate cyclase in the retina, contributing to understanding its biological activity. Phytother. Res. 2012, $26,73-77$. [CrossRef]

16. D'ACAMPORA Zellner, B.; Lo Presti, M.; Barata, L.E.; Dugo, P.; Dugo, G.; Mondello, L. Evaluation of leaf-derived extracts as an environmentally sustainable source of essential oils by using gas chromatography-mass spectrometry and enantioselective gas chromatography-olfactometry. Anal. Chem. 2006, 78. [CrossRef]

17. Almeida, M.R.; Fidelis, C.H.; Barata, L.E.; Poppi, R.J. Classification of Amazonian rosewood essential oil by Raman spectroscopy and PLS-DA with reliability estimation. Talanta 2013, 117, 305-311. [CrossRef]

18. Ye, M.; Sun, M.; Huang, D.; Zhang, Z.; Zhang, H.; Zhang, S.; Hu, F.; Jiang, X.; Jiao, W. A review of bacteriophage therapy for pathogenic bacteria inactivation in the soil environment. Environ. Int. 2019, 129. [CrossRef]

19. Holetz, F.B.; Pessini, G.L.; Sanches, N.R.; Cortez, D.A.; Nakamura, C.V.; Filho, B.P. Screening of some plants used in the Brazilian folk medicine for the treatment of infectious diseases. Mem. Inst. Oswaldo Cruz. 2002, 97, 1027-1031. [CrossRef]

20. Rosato, A.; Piarulli, M.; Corbo, F.; Muraglia, M.; Carone, A.; Vitali, M.E.; Vitali, C. In vitro synergistic antibacterial action of certain combinations of gentamicin and essential oils. Curr. Med. Chem. 2010, 17, 3289-3295. [CrossRef]

21. Jabir, M.S.; Taha, A.A.; Sahib, U.I. Linalool loaded on glutathione-modified gold nanoparticles: A drug delivery system for a successful antimicrobial therapy. Artif. Cells Nanomed Biotechnol. 2018, 46, 345-355. [CrossRef]

22. Vainstein, A.; Lewinsohn, E.; Pichersky, E.; Weiss, D. Floral fragrance. New inroads into an old commodity. Plant Physiol. 2001, 127, 1383-1389. [CrossRef] [PubMed]

23. Christensson, J.B.; Matura, M.; Gruvberger, B.; Bruze, M.; Karlberg, A.T. Linalool—A significant contact sensitizer after air exposure. Contact Dermat. 2010, 62. [CrossRef] [PubMed]

24. Bråred Christensson, J.; Andersen, K.E.; Bruze, M.; Johansen, J.D.; Garcia-Bravo, B.; Gimenez Arnau, A.; Goh, C.L.; Nixon, R.; White, I.R. Air-oxidized linalool: A frequent cause of fragrance contact allergy. Contact Dermat. 2012, 67. [CrossRef] [PubMed]

25. Audrain, H.; Kenward, C.; Lovell, C.R.; Green, C.; Ormerod, A.D.; Sansom, J.; Chowdhury, M.M.; Cooper, S.M.; Johnston, G.A.; Wilkinson, M.; et al. Allergy to oxidized limonene and linalool is frequent in the U.K. Br. J. Dermatol. 2014, 171. [CrossRef]

26. Martins, F.J.; Caneschi, C.A.; Vieira, J.L.; Barbosa, W.; Raposo, N.R. Antioxidant activity and potential photoprotective from amazon native flora extracts. J. Photochem. Photobiol. B Biol. 2016, 161. [CrossRef]

27. Oliveira de Souza, L.I.; Bezzera-Silva, P.C.; do Amaral Ferraz Navarro, D.M.; da Silva, A.G.; Dos Santos Correia, M.T.; da Silva, M.V.; de Figueiredo, R.C.B.Q. The chemical composition and trypanocidal activity of volatile oils from Brazilian Caatinga plants. Biomed. Pharmacother. 2017, 96. [CrossRef]

28. Dos Santos Sales, V.; Monteiro, Á.B.; Delmondes, G.A.; do Nascimento, E.P.; Sobreira Dantas Nóbrega de Figuêiredo, F.R.; de Souza Rodrigues, C.K.; Evangelista de Lacerda, J.F.; Fernandes, C.N.; Barbosa, M.O.; Brasil, A.X.; et al. Antiparasitic activity and essential oil chemical analysis of the piper tuberculatum jacq fruit. Iran. J. Pharm. Res. IJPR 2018, 17, 268.

29. Giongo, J.L.; Vaucher, R.A.; Da Silva, A.S.; Oliveira, C.B.; de Mattos, C.B.; Baldissera, M.D.; Sagrillo, M.R.; Monteiro, S.G.; Custódio, D.L.; Souza de Matos, M.; et al. Trypanocidal activity of the compounds present in Aniba canelilla oil against Trypanosoma evansi and its effects on viability of lymphocytes. Microb. Pathog. 2017, 103. [CrossRef]

30. Jackson, Y.; Wyssa, B.; Chappuis, F. Tolerance to Nifurtimox and Benznidazole in Adult Patients With Chronic Chagas' Disease. J. Antimicrob. Chemother. 2020, 75. [CrossRef]

31. Izumi, E.; Ueda-Nakamura, T.; Veiga, V.F.; Pinto, A.C.; Nakamura, C.V. Terpenes from Copaifera demonstrated in vitro antiparasitic and synergic activity. J. Med. Chem. 2012, 55. [CrossRef]

32. Santoro, G.F.; Cardoso, M.G.; Guimarães, L.G.; Mendonça, L.Z.; Soares, M.J. Trypanosoma cruzi: Activity of essential oils from Achillea millefolium L., Syzygium aromaticum L. and Ocimum basilicum L. on epimastigotes and trypomastigotes. Exp. Parasitol. 2007, 116, 283-290. [CrossRef] 
33. Villamizar, L.H.; Cardoso, M.G.; Andrade, J.; Teixeira, M.L.; Soares, M.J. Linalool, a Piper aduncum essential oil component, has selective activity against Trypanosoma cruzi trypomastigote forms at $4{ }^{\circ} \mathrm{C}$. Memórias Do Inst. Oswaldo Cruz. 2017, 112, 131-139. [CrossRef]

34. Suman Gupta, N. Visceral leishmaniasis: Experimental models for drug discovery. Indian J. Med. Res. 2011, 133, 27-39.

35. Do Socorro S Rosa, M.d.S.; Mendonça-Filho, R.R.; Bizzo, H.R.; de Almeida Rodrigues, I.; Soares, R.M.; Souto-Padrón, T.; Alviano, C.S.; Lopes, A.H. Antileishmanial activity of a linalool-rich essential oil from Croton cajucara. Antimicrob. Agents Chemother. 2003, 47. [CrossRef]

36. Dutra, F.L.; Oliveira, M.M.; Santos, R.S.; Silva, W.S.; Alviano, D.S.; Vieira, D.P.; Lopes, A.H. Effects of linalool and eugenol on the survival of Leishmania (L.) infantum chagasi within macrophages. Acta Trop. 2016, 164, 69-76. [CrossRef]

37. Vespa, G.N.; Cunha, F.Q.; Silva, J.S. Nitric oxide is involved in control of Trypanosoma cruzi-induced parasitemia and directly kills the parasite in vitro. Infect. Immun. 1994, 62. [CrossRef]

38. Kim, M.G.; Kim, S.M.; Min, J.H.; Kwon, O.K.; Park, M.H.; Park, J.W.; Ahn, H.I.; Hwang, J.Y.; Oh, S.R.; Lee, J.W.; et al. Antiinflammatory effects of linalool on ovalbumin-induced pulmonary inflammation. Int. Immunopharmacol. 2019, 74. [CrossRef]

39. Peana, A.T.; Marzocco, S.; Popolo, A.; Pinto, A. (-)-Linalool inhibits in vitro NO formation: Probable involvement in the antinociceptive activity of this monoterpene compound. Life Sci. 2006, 78. [CrossRef]

40. Salfinger, Y.; Tortorello, M.L. Compendium of Methods for the Microbiological Examination of Foods; American Public Health Association (APHA): Washington, DC, USA, 1992.

41. CLSI. Performance Standards for Antimicrobial disk and Dilution Susceptibility Tests for Bacteria Isolated from Animals, 4th ed.; CLSI: Wayne, PA, USA, 2009; p. 99.

42. Bauer, A.W.; Kirby, W.M.; Sherris, J.C.; Turck, M. Antibiotic susceptibility testing by a standardized single disk method. Am. J. Clin. Pathol. 1966, 45, 493-496. [CrossRef]

43. Re, R.; Pellegrini, N.; Proteggente, A.; Pannala, A.; Yang, M.; Rice-Evans, C. Antioxidant activity applying an improved ABTS radical cation decolorization assay. Free Radic. Biol. Med. 1999, 26, 1231-1237. [CrossRef]

44. El Babili, F.; Bouajila, J.; Souchard, J.P.; Bertrand, C.; Bellvert, F.; Fouraste, I.; Moulis, C.; Valentin, A. Oregano: Chemical analysis and evaluation of its antimalarial, antioxidant, and cytotoxic activities. J. Food Sci. 2011, 76. [CrossRef] [PubMed]

45. Campos, M.G.; Webby, R.F.; Markham, K.R.; Mitchell, K.A.; Da Cunha, A.P. Age-induced diminution of free radical scav-enging capacity in bee pollens and the contribution of constituent flavonoids. J. Agric. Food. Chem. 2003, 51. [CrossRef] [PubMed]

46. Rottini, M.M.; Amaral, A.C.F.; Ferreira, J.L.P.; Oliveira, E.S.C.; Silva, J.R.A.; Taniwaki, N.N.; Dos Santos, A.R.; Almeida-Souza, F.; de Souza, C.S.F.; Calabrese, K.S. Endlicheria bracteolata (Meisn.) essential oil as a weapon against Leishmania amazonensis: In vitro assay. Molecules 2019, 24, 2525. [CrossRef]

47. Da Silva, V.D.; Almeida-Souza, F.; Teles, A.M.; Neto, P.A.; Mondego-Oliveira, R.; Mendes Filho, N.E.; Taniwaki, N.N.; Abreu-Silva, A.L.; Calabrese, K.d.S.; Mouchrek Filho, V.E. Chemical composition of Ocimum canum Sims. essential oil and the antimicrobial, antiprotozoal and ultrastructural alterations it induces in Leishmania amazonensis promastigotes. Ind. Crop. Prod. 2018, 119, 201-208. [CrossRef]

48. Mosmann, T. Rapid colorimetric assay for cellular growth and survival: Application to proliferation and cytotoxicity assays. J. Immunol. Methods 1983, 65. [CrossRef]

49. Oliveira, I.S.S.; Colares, A.V.; Cardoso, F.O.; Tellis, C.J.M.; Chagas, M.S.S.; Behrens, M.D.; Calabrese, K.S.; Almeida-Souza, F.; Abreu-Silva, A.L. Vernonia polysphaera baker: Anti-inflammatory activity in vivo and inhibitory effect in lps-stimulated RAW 264.7 cells. PLoS ONE 2019, 14, e0225275. [CrossRef]

50. Teles, A.M.; Rosa, T.; Mouchrek, A.N.; Abreu-Silva, A.L.; Calabrese, K.D.S.; Almeida-Souza, F. Cinnamomum zeylanicum, Origanum vulgare, and Curcuma longa essential oils: Chemical composition, antimicrobial and antileishmanial activity. Evid Based Complement Alternat. Med. 2019, 2019, 2421695. [CrossRef]

51. Almeida-Souza, F.; Silva, V.D.D.; Silva, G.X.; Taniwaki, N.N.; Hardoim, D.J.; Buarque, C.D.; Abreu-Silva, A.L.; Calabrese, K.D.S. 1,4-Disubstituted-1,2,3-Triazole compounds induce ultrastructural alterations in leishmania amazonensis promastigote: An in vitro antileishmanial and in silico pharmacokinetic study. Int. J. Mol. Sci. 2020, 21, 6839. [CrossRef] 